\title{
Patterns of the tapeworm Raillietina trapezoides infection in the fat sand rat Psammomys obesus in Tunisia: season, climatic conditions, host age and crowding effects
}

\author{
E. FICHET-CALVET ${ }^{1 *}$, JUEFEI WANG ${ }^{1}$, I. JOMÂA ${ }^{2}$, R. BEN ISMAIL ${ }^{2}$ \\ and R. W. ASHFORD ${ }^{1}$ \\ ${ }^{1}$ Liverpool School of Tropical Medicine, Pembroke Place, Liverpool L3 5QA, UK \\ ${ }^{2}$ Laboratoire d'Epidémiologie et d'Ecologie Parasitaire, Institut Pasteur de Tunis, BP 74, 1002 Tunis Belvédère, Tunisie
}

(Received 18 May 2002; revised 15 October 2002; accepted 2 December 2002)

\section{SUMMARY}

The tapeworm Raillietina trapezoides was studied in a Tunisian population of the fat sand rat Psammomys obesus. Seasonal changes in the abundance of parasite and host were monitored in a longitudinal field survey lasting 20 months. In total 582 intestinal samples were collected during 10 trapping sessions between May 1995 and January 1997 and examined. The impact of abiotic and biotic factors on the prevalence and parasite burden were explored, using generalized linear models. $R$. trapezoides showed a seasonal pattern with most transmission occurring in summer and autumn. In August-September when the rodents were at low density and most adult (90-100\%) were infected. In winter, infections with $R$. trapezoides were highly prevalent in the cohort of adults only. The worm burden by number was also high in late summer and autumn. Prevalence and parasite burden by number or by biomass were highly age dependent. Season and age act in synergy so that the rodents were highly infected in late summer and autumn. Unusually dry conditions in winter seemed to increase prevalence and to reduce the number of worms. There was no difference between males and females in prevalence or parasite burden (by number or by biomass). Prevalence was not correlated with the relative density of the hosts whereas parasite burden depended upon their densities. The more numerous the worms were, the smaller they were individually, reflecting a crowding effect. The possibility of an immune response regulating $P$. obesus is discussed, in regard to the very high natural prevalence and the variation in worm burden, and compared with other parasite-host systems.

Key words: Raillietina trapezoides, Psammomys obesus, population structure, temporal dynamics, prevalence, parasite burden.

\section{INTRODUCTION}

Psammomys obesus Cretzschmar 1828, is a diurnal gerbillid rodent whose range extends from Mauritania to Syria and Saudi Arabia, and to the Red Sea Coast of Sudan (Fichet-Calvet et al. 2000 a). It lives in saline habitats, notably 'succulent halophytic steppes' or along wadi edges, where the main food plants, Chenopodiaceae, grow (Petter, 1961; Kam \& Degen, 1989; Zaime \& Gautier, 1989). It is the main reservoir host for zoonotic cutaneous leishmaniasis caused by the protozoan parasite, Leishmania major (Gunders et al. 1968; Ashford et al. 1977; Ashford, 2000). This is why its population biology was studied in Tunisia, in particular its reproduction (FichetCalvet et al. 1999) and its distribution in time and space at the regional scale (Fichet-Calvet et al. $2000 a)$.

The tapeworm, Raillietina trapezoides Janicki 1904, was originally described as Davainea

\footnotetext{
* Corresponding author: Laboratoire de Zoologie Mammifères et Oiseaux, Muséum National d'Histoire Naturelle, 55 rue Buffon, 75005 Paris, France. E-mail: calvet@mnhn.fr
}

trapezoides, from 'Mus variegatus' (=Arvicanthis niloticus) from Egypt. The species has been found in Israel, in gerbillid and dipodid rodents: Gerbillus spp., Meriones spp., P. obesus and Faculus jaculus (Wertheim, Schmidt \& Greenberg, 1986). The intermediate host(s) is unknown.

The study of the fat sand rat P. obesus in Tunisia involved the sampling of the population over a 2 -year period. It was based on a large sample size, providing an opportunity to correlate parasite infection with climatic conditions and demographic parameters. The aim of the present work is to test for any effect of abiotic (season, weather conditions) and biotic (host age, sex and density) factors on the infection rate (prevalence) and intensity in the rodent population.

\section{MATERIALS AND METHODS}

\section{Study site and sampling of host population}

The area is in the arid bioclimatic zone, with mean annual rainfall (1960-1995) of $260 \mathrm{~mm}$. The study was carried out $40 \mathrm{~km}$ south of Sidi Bouzid $\left(35^{\circ} 46^{\prime} \mathrm{N}, 9^{\circ} 36^{\prime} \mathrm{E}, 280 \mathrm{~m}\right.$ above sea level), on the 
Table 1. Weather records at Sidi Bouzid station between March 1995 and December 1996

(The rainfall (in mm), the number of rain days and the mean temperature (in ${ }^{\circ} \mathrm{C}$ ) are given for 2 months preceding each collection. The climatic period, dry or wet, are calculated from these 2 month records.)

\begin{tabular}{lcrlll}
\hline \hline Month & Rainfall & $\begin{array}{c}\text { Rain } \\
\text { days }\end{array}$ & Temperature & Session & $\begin{array}{l}\text { Climatic } \\
\text { period }\end{array}$ \\
\hline Mar. + Apr. 95 & $20 \cdot 2$ & 11 & $14 \cdot 7$ & May 95 & Dry \\
May + June 95 & $24 \cdot 0$ & 4 & $25 \cdot 4$ & July 95 & Dry \\
July + Aug. 95 & $76 \cdot 7$ & 12 & $30 \cdot 1$ & Sept. 95 & Wet \\
Sept. + Oct. 95 & $122 \cdot 7$ & 22 & $22 \cdot 1$ & Nov. 95 & Wet \\
Nov. + Dec. 95 & $27 \cdot 9$ & 17 & $14 \cdot 5$ & Jan. 96 & Dry \\
Jan. + Feb. 96 & $73 \cdot 3$ & 24 & $11 \cdot 6$ & Mar. 96 & Wet \\
Apr. + May 96 & $79 \cdot 5$ & 21 & $16 \cdot 0$ & June 96 & Dry \\
June + July 96 & $23 \cdot 1$ & 9 & $27 \cdot 5$ & Aug. 96 & Dry \\
Sept. + Oct. 96 & $63 \cdot 7$ & 9 & $22 \cdot 7$ & Nov. 96 & Dry \\
Nov. + Dec. 96 & $12 \cdot 8$ & 2 & $14 \cdot 3$ & Jan. 97 & Dry \\
\hline \hline
\end{tabular}

edge of a sebcha ('succulent halophytic steppe' of Le Houerou \& Le Floc'h, (1995)). The vegetation was predominantly Chenopodiaceae, Salsola, Suaeda and Arthrocnemum species, with occasional Atriplex sp., representing the much disturbed remnants of the edge of the sebcha (Ozenda, 1991). The 100 ha site was traversed by earth dykes some $2 \mathrm{~m}$ high, constructed for flood control, between which were cultivated plots of wheat, separated by bands of natural vegetation (Fichet-Calvet et al. 2000 a). Samples were collected at 7 to 13 -week intervals, 10 times between May 1995 and January 1997, as described by Fichet-Calvet et al. 1999). For each trapping session, the rainfall, the number of rain days and the mean temperature during the 2 previous months are presented in the Table 1. According to Gaussen's convention (1975), the climatic conditions are defined as wet in September and November 1995 and March 1996 whereas the other collections were made under dry conditions (Fichet-Calvet et al. 1999).

\section{Host population parameters}

Relative abundance was measured as the number of captures per $100 \mathrm{~m}$ of trap line, each line varying from 60 to $280 \mathrm{~m}$ (Fichet-Calvet et al. 1999). Two kinds of traps were used, pincer traps on dykes and wire mesh cage traps on the residual band of the sebcha. The relative abundance is considered here as the mean of the 2 trapping indices ((pincer abundance index + cage abundance index)/2). Animals were killed as part of the study of cutaneous leishmaniasis, by complete cardiac exsanguination carried out under anaesthetic. They were weighed on a top pan balance to $1 \mathrm{~g}$ and were classified as sexually active if females were pregnant or lactating and if males had seminal vesicles more than $10 \mathrm{~mm}$ in length.

The weight of the desiccated eye lens is considered as the best indirect measure of age for mammals (Lord, 1959; Martinet, 1966; Morris, 1971). This clearly distinguishes young animals from older individuals with similar weights or body sizes. Eyes were removed and preserved for at least 2 weeks in $10 \%$ formalin, then the lens was extracted, dried for $2 \mathrm{~h}$ at $100{ }^{\circ} \mathrm{C}$ and weighed on a top pan balance to $0 \cdot 1 \mathrm{mg}$. The combined weight of both lenses was used. In our study, the correlation between eye lens weight (ELW) and age was not established precisely, as no standard curve was available, but we were able to differentiate 4 age classes comprising (i) juveniles under 2 months (ELW $<20 \mathrm{mg}$ ), (ii) young adult animals 2-4 months old $(\mathrm{ELW}=[20-30] \mathrm{mg})$, (iii) adults $4-6$ months old $(\mathrm{ELW}=[30-40] \mathrm{mg})$ and (iv) adults over 6 months old (ELW $\geqslant 40 \mathrm{mg}$ ).

\section{Detection and identification of parasite infections}

During dissections of $P$. obesus, the small intestine was opened longitudinally and the presence or absence of tapeworms was noted. From September 1995, each intestine was preserved in $10 \%$ formalin. Parasites were later counted and weighed. The wet weight was measured to the nearest $0 \cdot 001 \mathrm{~g}$ after each group of worms had been carefully blotted to free them of excess liquid. Selected specimens were flattened and fixed with Bouin's solution for identification. These were stained with acetocarmine and differentiated with acid alcohol, then dehydrated, cleared, and mounted in Canada balsam. All specimens were identified, with the assistance of Dr R. A. Bray of the Natural History Museum, London, as Raillietina trapezoides (Janicki, 1904).

\section{Data analysis}

According to the reproductive cycle in $P$. obesus in this area (Fichet-Calvet et al. 1999), the seasons were partitioned as follows. (i) Spring for May 1995 and March 1996 when the population was 
Table 2. The structure of the sampled host population by session of capture, host sex, host age and host relative density

(Host age is presented by class of eye lens weight in $\mathrm{mg}(\mathrm{elw})$. Relative density corresponds to the number of rats trapped per $100 \mathrm{~m}$ (Fichet-Calvet et al. 1999). See Material and Methods section for further explanation.)

\begin{tabular}{|c|c|c|c|c|c|c|c|}
\hline Session & Females & Males & elw $<20$ & $\mathrm{elw}=[20-30]$ & $\mathrm{elw}=[30-40]$ & elw $\geqslant 40$ & Relative density \\
\hline May 95 & 37 & 37 & 28 & 29 & 16 & 1 & $21 \cdot 0$ \\
\hline July 95 & 9 & 11 & 0 & 8 & 9 & 3 & $3 \cdot 3$ \\
\hline Sept. 95 & 31 & 25 & 2 & 0 & 34 & 20 & $2 \cdot 7$ \\
\hline Nov. 95 & 32 & 29 & 6 & 34 & 1 & 20 & $8 \cdot 0$ \\
\hline Jan. 96 & 35 & 30 & 34 & 21 & 1 & 9 & $14 \cdot 9$ \\
\hline Mar. 96 & 47 & 56 & 74 & 21 & 5 & 3 & $27 \cdot 5$ \\
\hline June 96 & 20 & 27 & 4 & 31 & 10 & 2 & $13 \cdot 6$ \\
\hline Aug. 96 & 21 & 24 & 0 & 0 & 28 & 17 & $3 \cdot 5$ \\
\hline Nov. 96 & 20 & 23 & 0 & 0 & 4 & 39 & $2 \cdot 4$ \\
\hline Jan. 97 & 29 & 39 & 0 & 0 & 0 & 68 & $6 \cdot 5$ \\
\hline
\end{tabular}

Table 3. Logistic regression results for Raillietina trapezoides infection in Psammomys obesus in a global model (5 variables) and a restricted model (3 variables)

$(\mathrm{elw}=$ eye lens weight in $\mathrm{mg} ; \mathrm{ai}=$ abundance index in number of rats trapped per $100 \mathrm{~m} . n=577$. Winter, wet conditions and male status serve as reference in this analysis and are thus not presented here.)

\begin{tabular}{|c|c|c|c|c|}
\hline \multirow[b]{2}{*}{ Variable } & \multicolumn{2}{|c|}{ Global model } & \multicolumn{2}{|c|}{ Restricted model } \\
\hline & $P$ & Odds ratio & $P$ & Odds ratio \\
\hline Season autumn & $0 \cdot 599$ & $1 \cdot 234$ & $0 \cdot 244$ & $1 \cdot 425$ \\
\hline Season spring & $0 \cdot 013$ & $0 \cdot 219$ & $<0.0001$ & $0 \cdot 162$ \\
\hline Season summer & $0 \cdot 549$ & $1 \cdot 181$ & $0 \cdot 570$ & $1 \cdot 175$ \\
\hline Season late summer & $0 \cdot 040$ & $2 \cdot 793$ & $<0 \cdot 0001$ & $3 \cdot 467$ \\
\hline Climatic period dry & $0 \cdot 040$ & $1 \cdot 531$ & $0 \cdot 018$ & $1 \cdot 590$ \\
\hline Host sex female & $0 \cdot 900$ & $1 \cdot 017$ & & \\
\hline $\begin{array}{l}\text { Host age } \\
(4 \cdot 6 \leqslant \mathrm{elw} \leqslant 62 \cdot 4)\end{array}$ & $<0 \cdot 0001$ & $1 \cdot 125$ & $<0 \cdot 0001$ & $1 \cdot 129$ \\
\hline $\begin{array}{l}\text { Host relative density } \\
(2 \cdot 4 \leqslant \text { ai } \leqslant 27 \cdot 5)\end{array}$ & $0 \cdot 580$ & $0 \cdot 975$ & & \\
\hline
\end{tabular}

composed of many juveniles, and sexually active adults; (ii) summer for July 1995 and June 1996 when the adults were sexually inactive; (iii) late summer for September 1995 and August 1996 when reproduction was recommencing; (iv) autumn for November 1995 and 1996 when adults born the previous spring were reproducing and (iv) winter for January 1996 and 1997 when young and old adults were reproducing. Season, climatic period, host sex, age and relative density effects on prevalence were analysed by multiple logistic regression using a binary factor (infected $=1$; uninfected $=0$ ) as the dependent variable and season (5 levels: spring, summer, late summer, autumn and winter), climatic period (2 levels: wet and dry), host sex (2 levels), host age (continuous: elw) and host relative density (continuous: abundance index) as the independent variables. This analysis was performed with Systat 9, SPSS Inc. (1998) and followed the guidelines presented by Falissard (1998).

In each infected individual, the parasite burden is presented by number and by biomass. This corresponds to intensity of infection according to Margolis et al. (1982). Season, host sex, host density and age effects on parasite burden by number and by biomass were analysed by ANOVA, using the quantitative factors, tapeworm number and biomass, as the dependent variables and season (5 levels, see above), climatic period (2 levels), sex (2 levels), host age $(4$ levels: elw $<20, \quad$ elw $=[20-30]$, elw $=[30-40]$ and elw $\geqslant 40)$ and host density (3 levels: low when ai $=2 \cdot 4,2 \cdot 7,3 \cdot 5,6 \cdot 5$, medium when $\mathrm{ai}=8 \cdot 0,13 \cdot 6,14.9$ and high when $\mathrm{ai}=27 \cdot 5$ ) as the independent variables. This analysis was performed with SuperAnova 1.1, Abacus Concept Inc. (1989).

The crowding effect was analysed by simple regression using the weight of individual tapeworms as the dependent variable and the number of tapeworms as the independent variable. This analysis was performed with Statview 5, SAS Institute Inc. (1998).

As the macroparasites often show an aggregated distribution following a negative binomial law 

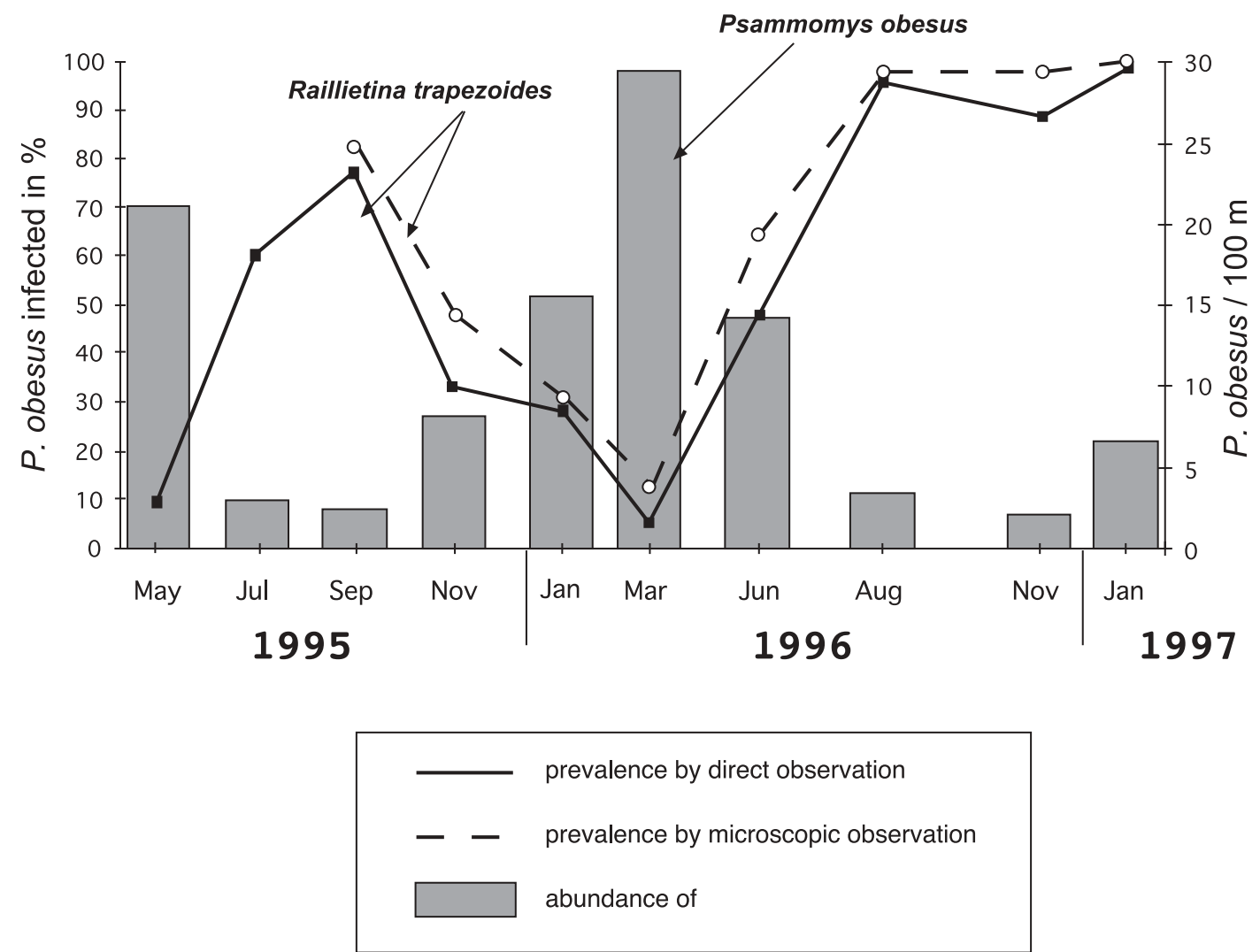

Fig. 1. Prevalence of Raillietina trapezoides and abundance of its host, Psammomys obesus, in the same period.

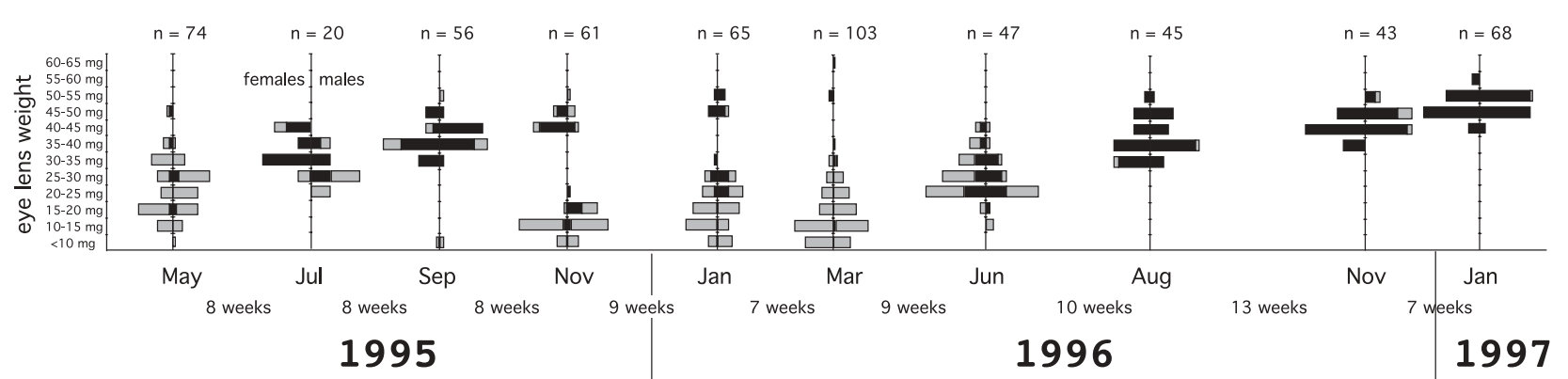

Fig. 2. Distribution of Raillietina trapezoides in Psammomys obesus by age (eye lens weight) and sex of host and by season. Each pyramid corresponds to the proportion of females (left) and males (right) sampled at each session (shaded area) in which the proportion of infected individuals is included (black area). To equalize the pyramid surface between small and large samples, the length of each horizontal bar reflects the proportion of individuals in each collection (total length of bars in each collection $=1)$. $n$, Number of $P$. obesus sampled.

(Wilson et al. 2002), we tested the distribution of the number and the biomass of the tapeworms by using the formula:

$$
\begin{aligned}
1= & 1 / q^{k}+k\left(p / q^{k+1}\right)+\ldots \\
& +[(k(k+1) \ldots(k+n-1)) / n !]\left[p^{n} / q^{k+n}\right],
\end{aligned}
$$

where $p=$ mean $/ n, q=1+p$ and $k=-\log p$ (first observed class)/log $q . \quad k$ is the negative binomial exponent qualifying the degree of aggregation. Frequency distribution for goodness to negative binomial and normal were then tested by $\chi^{2}$.
RESULTS

A total of 582 P. obesus were examined between May 1995 and January 1997. The overall prevalence of infection in all rodents in the survey was $47 \%(276 / 582)$ when measured during autopsy. The second, more meticulous examination, by dissecting microscope, added around $4 \%$ to the prevalence estimate. As the time-series was shorter for the latter specimens, autopsy observations were used for the longitudinal study of prevalence. The structure of the sampled host population is presented in the Table 2 . 

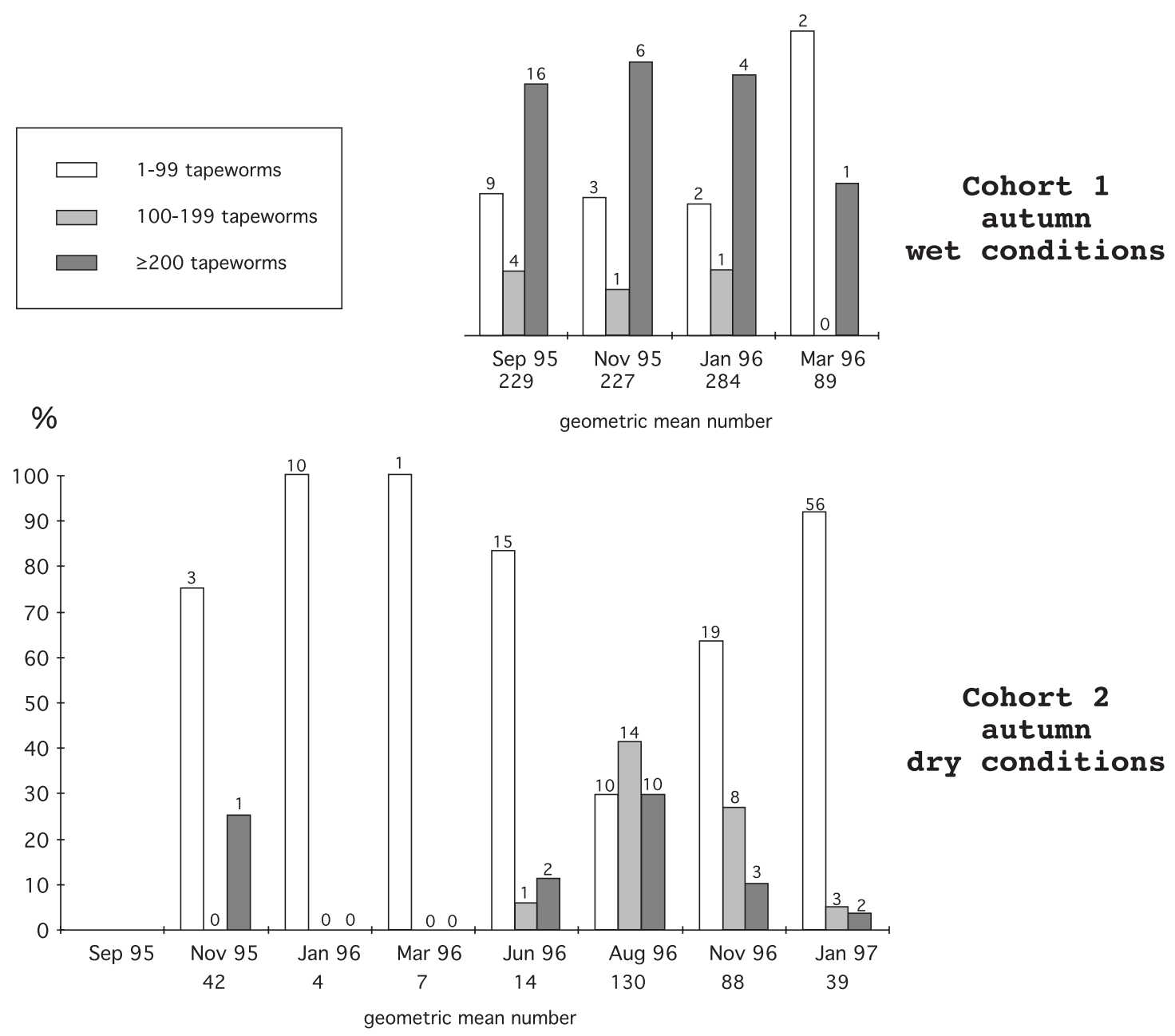

Fig. 3. Distribution of numerical parasite burden by season and by host cohort.

\section{The prevalence}

The influence of season, climatic period, host sex, age and relative density on prevalence was analysed by multiple logistic regression. The results are summarized in Table 3.

In the global model, the main effect on prevalence was due to host age, and was highly significant. The season as spring and late summer were also significant with odds ratios of 0.219 and 2.793 respectively. This indicates that prevalence was about $1 / 5$ lower in spring and 2.8 higher in late summer compared to winter. The climatic period was significant with an odds ratio indicating that prevalence was 1.5 higher in dry than in wet conditions. The host sex and relative density were not significant, leading to restrict the model to 3 variables only: season, climatic period and host age (Table 3 ). In a third step, a 3-way interaction 'season $\times$ climatic period $\times$ host age' was included in the restricted model, which was significant in dry autumn $(P=0 \cdot 003)$ whereas the main factor 'climatic period' turned to non-significant $(P=0.058)$. This is illustrated in Fig. 1, which shows the concomitant temporal dynamics of $R$. trapezoides and P. obesus. The prevalence of $R$. trapezoides varied considerably between winter (2\% in March 1996) and summer (95\% in August 1996). The host age effect is illustrated in Fig. 2 where the age structure is presented for each collection. Infected individuals were present in each collection and in each ELW class over $10 \mathrm{mg}$. Infection thus took place from June when the young were still in the nest and the proportion increased in the old adult classes. The succession of age pyramids shows 2 cohorts; one with individuals born before summer 1995 (cohort 1) and the other with individuals born after summer 1995 (cohort 2).

\section{Parasite burden: variation by season, climatic} conditions, host sex, host age and host density

Quantitative information was available for 207 infected animals. Between 1 and 1514 tapeworms were counted in individual hosts: $63 \%(130 / 207)$ of infected animals harboured between 1 and 99 worms, $15 \%(32 / 207)$ between 100 and 199 , and $22 \%$ $(45 / 207)$ more than 199 . Figure 3 shows this distribution by session of trapping. As the variable 'number of tapeworms' was highly aggregated (mean $=$ 130 , variance $=30244, k=0 \cdot 6$ ) but not conform to a negative binomial distribution $\left(\chi^{2}=27 \cdot 970\right.$, 
Table 4. Extrinsic and intrinsic sources of variation in the Raillietina trapezoides burden by number or in biomass in Psammomys obesus through ANOVA

\begin{tabular}{|c|c|c|c|c|c|}
\hline \multirow[b]{2}{*}{ Source of variation } & \multirow[b]{2}{*}{ D.F. } & \multicolumn{2}{|c|}{ Number } & \multicolumn{2}{|c|}{ Biomass } \\
\hline & & $\mathrm{F}$ & $P$ & $\mathrm{~F}$ & $P$ \\
\hline Season & 3 & 8.905 & $<0 \cdot 0001$ & $1 \cdot 907$ & $0 \cdot 1299$ \\
\hline Climatic period & 1 & $4 \cdot 165$ & $0 \cdot 0427$ & $20 \cdot 580$ & $<0.0001$ \\
\hline Host sex & 1 & $0 \cdot 020$ & 0.8899 & $0 \cdot 014$ & $0 \cdot 9061$ \\
\hline Host age & 3 & $9 \cdot 888$ & $<0 \cdot 0001$ & $5 \cdot 208$ & $0 \cdot 0018$ \\
\hline Host density & 1 & $16 \cdot 034$ & $<0 \cdot 0001$ & $18 \cdot 339$ & $<0.0001$ \\
\hline Season $\times$ climatic period & 1 & $2 \cdot 771$ & $0 \cdot 0977$ & $3 \cdot 216$ & $0 \cdot 0745$ \\
\hline Season $\times$ host age & 6 & $6 \cdot 842$ & $<0 \cdot 0001$ & $3 \cdot 173$ & $0 \cdot 0055$ \\
\hline $\begin{array}{l}\text { Season } \times \text { climatic period } \\
\times \text { host age }\end{array}$ & 1 & $1 \cdot 641$ & $0 \cdot 2018$ & $0 \cdot 216$ & $0 \cdot 6424$ \\
\hline
\end{tabular}

$P<0 \cdot 0001$, D.F. $=3)$, it was normalized by $\log _{10}$ transformation which gave the best adjustment $\left(\chi^{2}=\right.$ $7 \cdot 75, P=0 \cdot 933$, D.F. $=13$ ) for analysis by ANOVA. This analysis showed that the effects of season, climatic period, host age and host density were significant (Table 4). Rodents were more intensively infected in late summer and autumn than in other seasons (Fig. 4A), in wet than in dry conditions (Fig. 4B), in low rather than medium or high densities (Fig. 4C) and in young animals than in adults (Fig. 4D). Because the season in combination with climatic period or with age or with these two factors could have an effect on parasite burden, the 2-way and 3-way interactions between them were included in the model. Only the 2 -way interaction 'season $x$ host age' was significant. This is illustrated in Fig. 5 that shows different patterns between seasons. The 2-4 month class was more intensively infected in summer than in winter whereas the trend was inverse when rodents belonged to the $4-6$ month class. When the rodents became older, over 6 months, the season seemed to have no influence on parasite burden whereas the dry conditions depressed the tapeworm number significantly $\left(\mathrm{F}_{\mathbf{1 , 1 3 4}}=12 \cdot 411\right.$, $P=0.0006)$. The age effect mentioned above is particularly illustrated in the summer sample. Host sex has no effect on parasite burden by number.

The tapeworm biomass varied between 10 and $1780 \mathrm{mg}$, and showed an aggregated distribution $($ mean $=328 \mathrm{mg}$, variance $=57386, k=2 \cdot 4)$, but this again did not conform to a negative binomial distribution $\left(\chi^{2}=16 \cdot 132, P<0 \cdot 05\right.$, D.F. $\left.=7\right)$. Figure 6 shows this distribution by session of trapping. This variable was normalized by square root transformation which gave a better adjustment $\left(\chi^{2}=6 \cdot 646\right.$, $P=0 \cdot 827$, D.F. $=11)$ than a $\log _{10}$ transformation $\left(\chi^{2}=14 \cdot 482, P=0 \cdot 207\right.$, D.F. $\left.=11\right)$. Except for season, the ANOVA showed the same significant effects as for tapeworm number i.e. climatic period, host age, host density and the 2 -way interaction 'season $\times$ host age' (Table 4). The effects of each factor are illustrated in Fig. 4E-H, which shows some opposite trends to those for tapeworm number.

In each model, tapeworm biomass (in model by number) or tapeworm number (in model by biomass), entered as a covariate in a second step, was highly significant $\quad\left(\mathrm{F}_{1,207}=49 \cdot 757, \quad P<0 \cdot 0001\right)$ indicating that these two variables were strongly correlated.

\section{Parasite burden : a crowding effect}

To analyse the relation between the number and the biomass of tapeworms, the weight of each worm was calculated by dividing the biomass by the number. The new variable 'weight of individual tapeworms' varied between $0 \cdot 149$ and $100 \mathrm{mg}$ in an aggregated distribution $($ mean $=9 \cdot 646$, variance $=197 \cdot 983)$ and was normalized by $\log _{10}$ transformation $\left(\chi^{2}=6 \cdot 553\right.$, $P>0.900$, D.F. $=13)$. The simple regression using $\log _{10}$ weight/tapeworm as dependent variable and $\log _{10}$ number of tapeworms as independent variable was highly significant $(r=0.833, P<0.0001, n=$ 207). This is illustrated in Fig. 7 where the more numerous the worms in an infection, the smaller they were individually.

\section{ISCUSSION}

\section{Season effect}

The prevalence of $R$. trapezoides in P. obesus was found to vary between $2 \%$ in late spring, and $100 \%$ in late autumn. This variation of prevalence through the year justifies a longitudinal approach and comparison with other cestode infections would be valid in homologous seasons only. A recent study in the Sinai (Behnke et al. 2000) showed 18.5\% (4/27) prevalence of the intestinal cestode Rodentolepis negevi in the spiny mouse Acomys cahirinus in May-June whereas, in our study, the prevalence of $R$. trapezoides rose to $50 \%$ in P. obesus in the same 

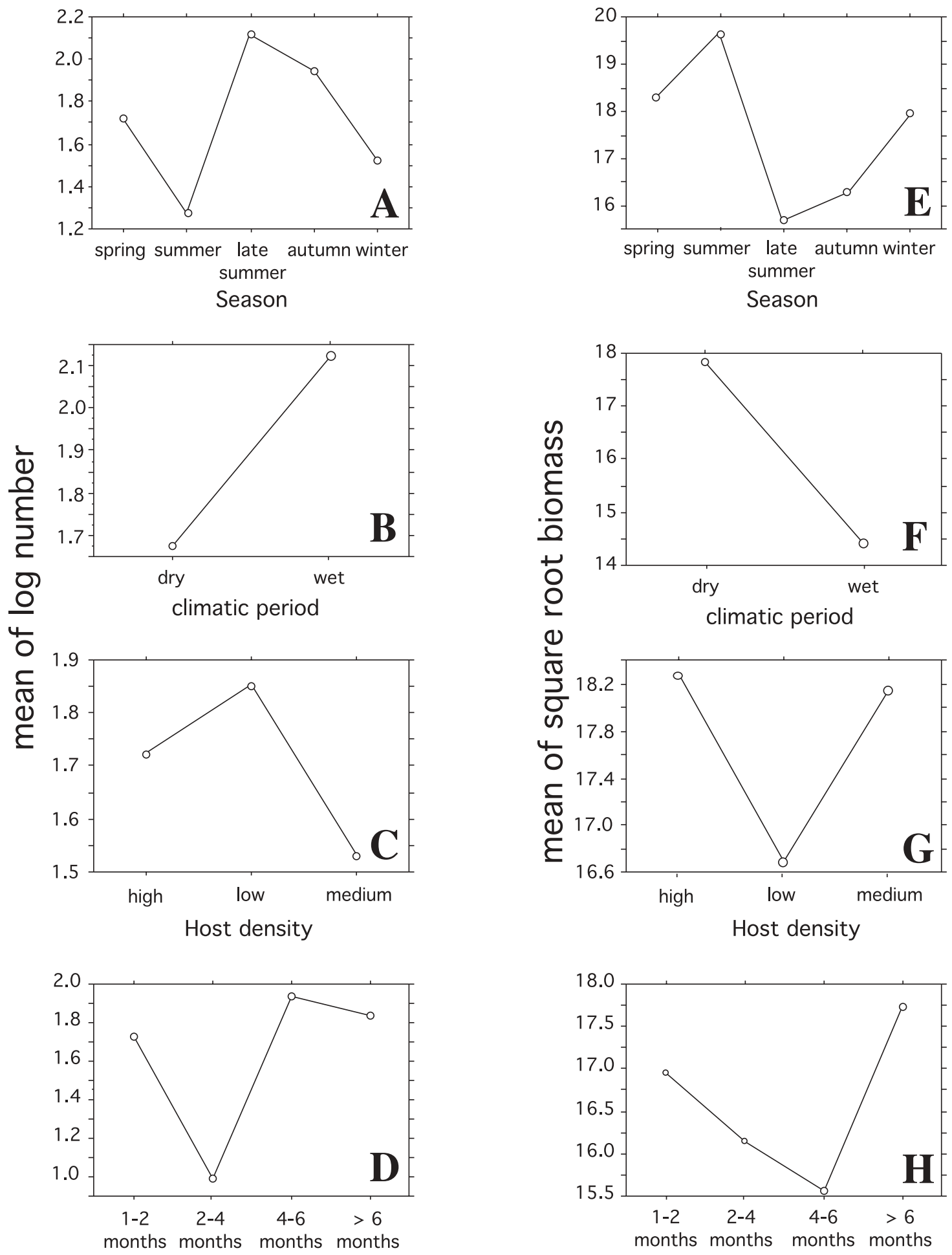

Host age

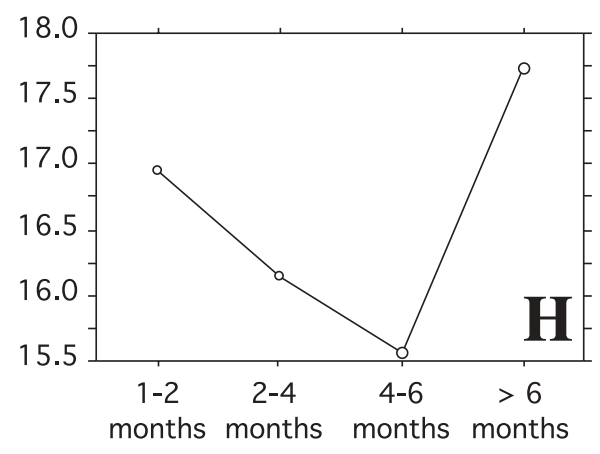

Host age

Fig. 4. Main effects of season, climatic period, host density and host age on the parasite burden by number (A-D) and on the parasite burden by biomass $(\mathrm{E}-\mathrm{H})$.

months. As the rodents were collected in similar habitats in the two studies, wadi gardens in the Sinai and salt lowland in Tunisia, this difference in prevalence indicates that $R$. trapezoides is much more common than $R$. negevi in those habitats. In temperate climates such as Ireland, the prevalence of Catenotaenia lobata in the wood mouse Apodemus sylvaticus varied between $2 \%$ and $67 \%$ with the highest values occurring in winter and in spring (Montgomery \& Montgomery, 1988). In Finland, the prevalence of Catenotaenia sp. in the bank vole Clethrionomys glareolus (Haukisalmi, Henttonen 


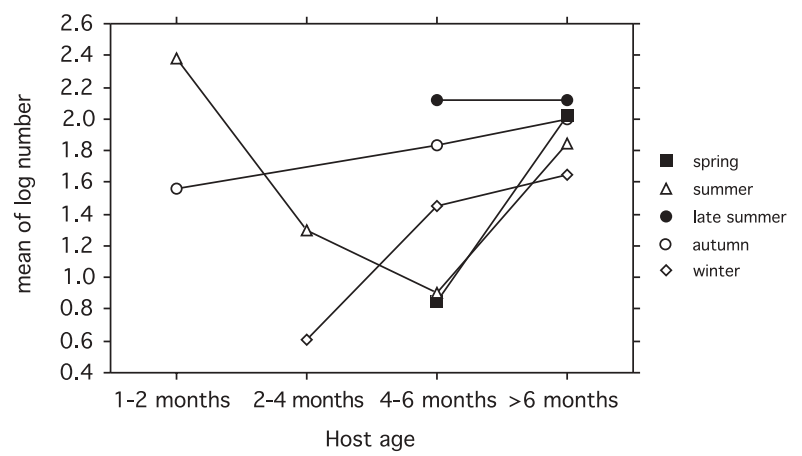

Fig. 5. Interaction effects of season and host age on the parasite burden by number.

\& Tenora, 1988) varied between $10 \%$ and $40 \%$ with the maximum in spring, in overwintered voles. The parasite burden follows a seasonal pattern with a low number of worms in summer and a high number of worms in late summer and autumn.

\section{Host age effect}

This seasonal influence is highly dependent on the structure of the host population through the age effect. Older hosts have a higher probability of being infected. The host age structure is dependent on the reproduction period. Following abundant reproduction during autumn-winter 1995-1996, the rodent population comprised a large proportion of juveniles and young adults in March 1996. Lack of reproduction during the following 6 months led to an ageing population in January 1997, as illustrated by a high-set population pyramid (Fichet-Calvet et al. 1999). Since P. obesus breeds only in the winter, these numerous and heavily infected rodents in the summer were all adults. As the global and restricted model showed in this study, this factor is fundamental and has to be considered before season to explain the variation in prevalence in the longitudinal survey. The dominant effect of age has been pointed out in rodents infected with other parasites, e.g. cestodes (Behnke et al. 1993, 1999), trematodes (Duplantier \& Sène, 2000), protozoan (Turner, 1986), bacteria (Godeluck et al. 1994; Fichet-Calvet et al. 2000b) and virus (Mills et al. 1992). Kisielewska (1971) proposed to use the prevalence and intensity of infection with intestinal helminths as age indicator in common voles, Microtus arvalis. The strong correlation between prevalence and age indicates also that $P$. obesus is susceptible throughout its life. In addition, the positive age effect on parasite burden by number suggests that $P$. obesus can be reinfected after a first infection and accumulate worms in their intestines. The high worm burden (by number) in early summer and autumn supports this hypothesis. However, Munger \& Karasov (1991) showed a decreasing prevalence of Hymenolepis citelli in the white-footed mouse, Peromyscus leucopus, with time. In their experiments, the prevalence decreased to $30 \%$ thirty days after infection in laboratory experiments and to $55 \%$ three months after infection in nature. The same phenomenon was observed in the deer mouse, P. maniculatus infected by the same worm (Wassom, Guss \& Grundmann, 1973) and for the better known worm, H. diminuta infecting rats (Andreassen et al. 1999). According to these studies, an expulsion mechanism seems to be the rule for intestinal cestodes. In our study, it is probable that $R$. trapezoides was regularly acquired throughout the year with a higher transmission rate in summer in combination with such an expulsion mechanism. When the overall sample is analysed, expulsion could be obscured by a higher rate of acquisition. In the restricted sample from August 1996 to January 1997, there is a decrease in the number of tapeworms per host. This trend could reflect a higher expulsion mechanism at this time or a higher mortality rate in heavy infected rodents in dry conditions.

\section{Climatic conditions}

The second year of the study was particularly dry, with only $144 \mathrm{~mm}$ rainfall, in 18 rainy days between June and December and we wanted to test for any influence of these climatic differences on the transmission of the tapeworm. The prevalence depended on the climatic period, with the highest rate of infection occurring in dry conditions. Nevertheless, this variable became non-significant when interaction 'season $\times$ climatic period $\times$ host age' was included in the model, suggesting that drought had an impact only in autumn and not in other seasons. Additionally, the burden by number is lower in dry than in wet conditions. This suggests that bad weather conditions such as the lack of rainfall in autumn-winter 1996-1997 lead to a decrease of the worms in adults. Again, this could be due to a stronger expulsion mechanism when food is poorly available and/or a higher mortality rate in heavily infected rodents. Because the rodents at this time needed to explore a larger home range and also to disperse more for providing green leaves and water intake, the predation risk could be higher then, than in wet conditions.

\section{Host density effect}

Even though the highest prevalences were seen when the hosts were all adults, and the population density was low, the host density had no influence on prevalence when season, climatic conditions and host age were taken into account. A similar pattern of host abundance and parasite prevalence was seen in Bartonella spp. in the same host (Fichet-Calvet et al. $2000 \mathrm{~b}$ ). Both of these parasites presumably depend on invertebrates for their transmission, and the abundance of intermediate hosts in summer 


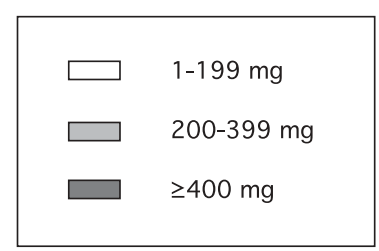

$\%$

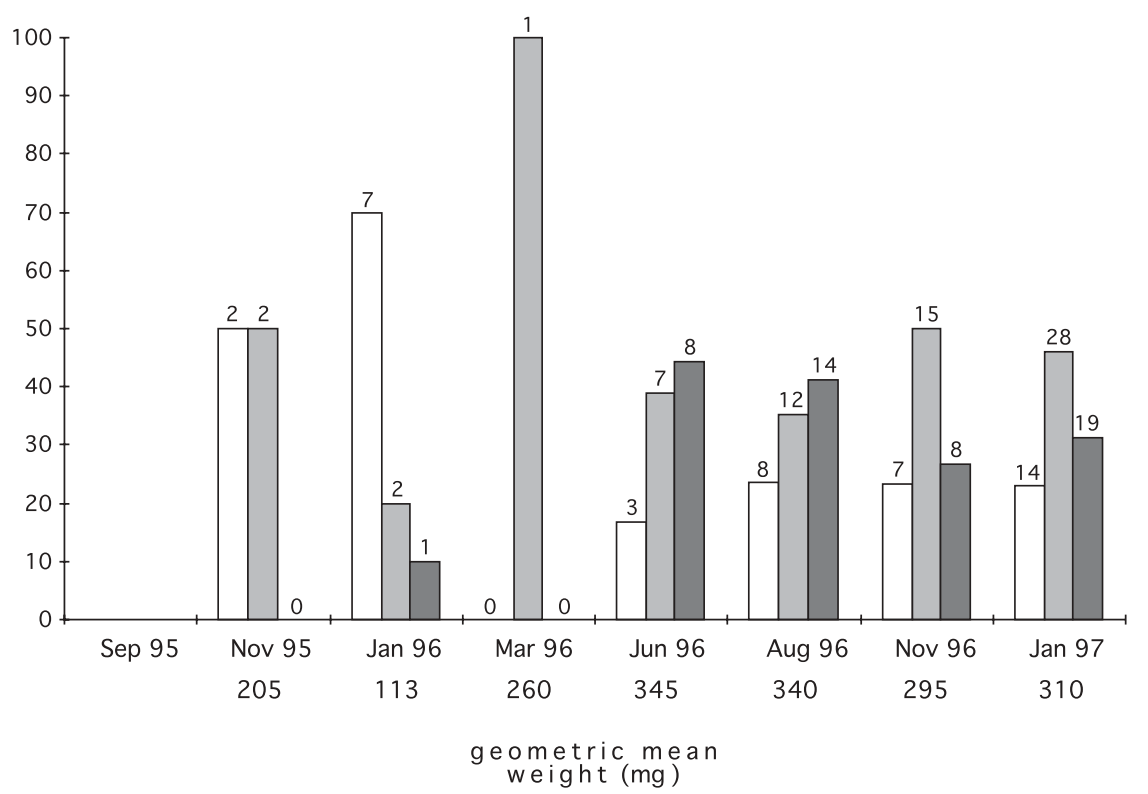

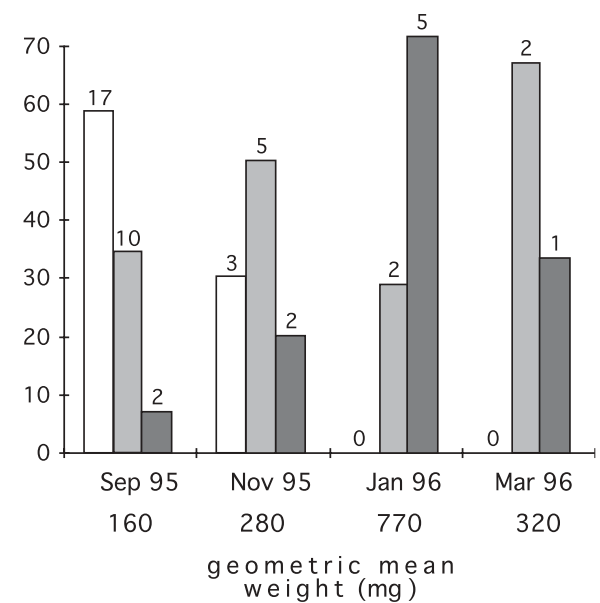

weight (mg)

\section{Cohort 1 autumn wet conditions}

\author{
Cohort 2 \\ autumn \\ dry conditions
}

Fig. 6. Distribution of parasite biomass, by season and by host cohort.

explains the high rate of transmission in summer. In other host-parasite combinations where the rodent is the definitive host and the arthropod is the intermediate host, this trend between prevalence and host density may be even more general. In early studies in Norway on rodent densities and parasites, the prevalence of Aprostatandrya macrocephala in the bank vole Clethrionomys glareolus was high when the host population density was at its lowest, and was low when the host population was at its highest (Tenora, Wiger \& Barus, 1979). In Finland, the prevalence of other intestinal cestodes such as Catenotcria sp. infecting the same species of rodent, was studied over 12 years by Haukisalmi \& Henttonen (1990) who found a negative correlation between prevalence and density. More recently, Decker, Duszynski \& Patrick, (2001) showed a similar pattern for the kangaroo rats Dipodomys ordii and D. merriami infected with Raillietina sp. in a 10-year survey of a rodent community in New Mexico (USA). In their study, one other cestode, Hymenolepis sp. was also negatively correlated with $D$. spectabilis and
D. merriami. Nevertheless in these two long-term studies, the authors showed also no correlation in model such as C. glareolus/Paranocephala kalelei (Haukisalmi \& Henttonen, 1990) and D. merriamil Oochoristica sp. (Decker et al. 2001). This indicates that the dependence is not the rule for dixenous cestodes infecting rodents as definitive hosts. More investigation on first, the identity and second, the fluctuations of the intermediate host are required to understand why prevalence is sometimes dependent on, and sometimes independent of rodent density.

Conversely, the host density had an effect on parasite burden by increasing the number of worms in low densities which mainly correspond to late summer. We can suggest that this effect is probably a consequence of an increase in insectivory. The intermediate host is probably an insect (as a Tenebrionide for $H$. diminuta) and could be eaten in higher proportion in summer or in dry autumn when saltbushes are desiccated and contain high concentrations of salt and the populations are at low density. 
Table 5. Summary of abiotic and biotic effects on prevalence and intensity of infection of Raillietina trapezoides in Psammomys obesus

$(+$ or $-=$ positive or negative effect at the noted level. \pm indicates an intermediary position of the level effect.)

\begin{tabular}{|c|c|c|c|}
\hline Variable & Prevalence & $\begin{array}{l}\text { Intensity } \\
\text { (number) }\end{array}$ & $\begin{array}{l}\text { Intensity } \\
\text { (biomass) }\end{array}$ \\
\hline Season & $\begin{array}{l}\text { + Late summer } \\
\text {-Spring }\end{array}$ & $\begin{array}{l}\text { + Late summer, } \\
\text { autumn } \\
\pm \text { Spring, winter } \\
\text { - Summer }\end{array}$ & Test N.s. \\
\hline Climatic period & + Dry & $\begin{array}{l}+ \text { Wet } \\
- \text { Dry }\end{array}$ & $\begin{array}{l}+ \text { Dry } \\
- \text { Wet }\end{array}$ \\
\hline Host sex & None & None & None \\
\hline Host age & + & $\begin{array}{l}+>4 \text { Months } \\
\pm 1-2 \text { Months } \\
-2-4 \text { Months }\end{array}$ & $\begin{array}{l}+1-2 \&>6 \text { Months } \\
\pm 2-4 \text { Months } \\
-4-6 \text { Months }\end{array}$ \\
\hline Host density & None & $\begin{array}{l}+ \text { Low } \\
\pm \text { High } \\
\text { - Medium }\end{array}$ & $\begin{array}{l}\text { + High, Medium } \\
\text { - Low }\end{array}$ \\
\hline
\end{tabular}

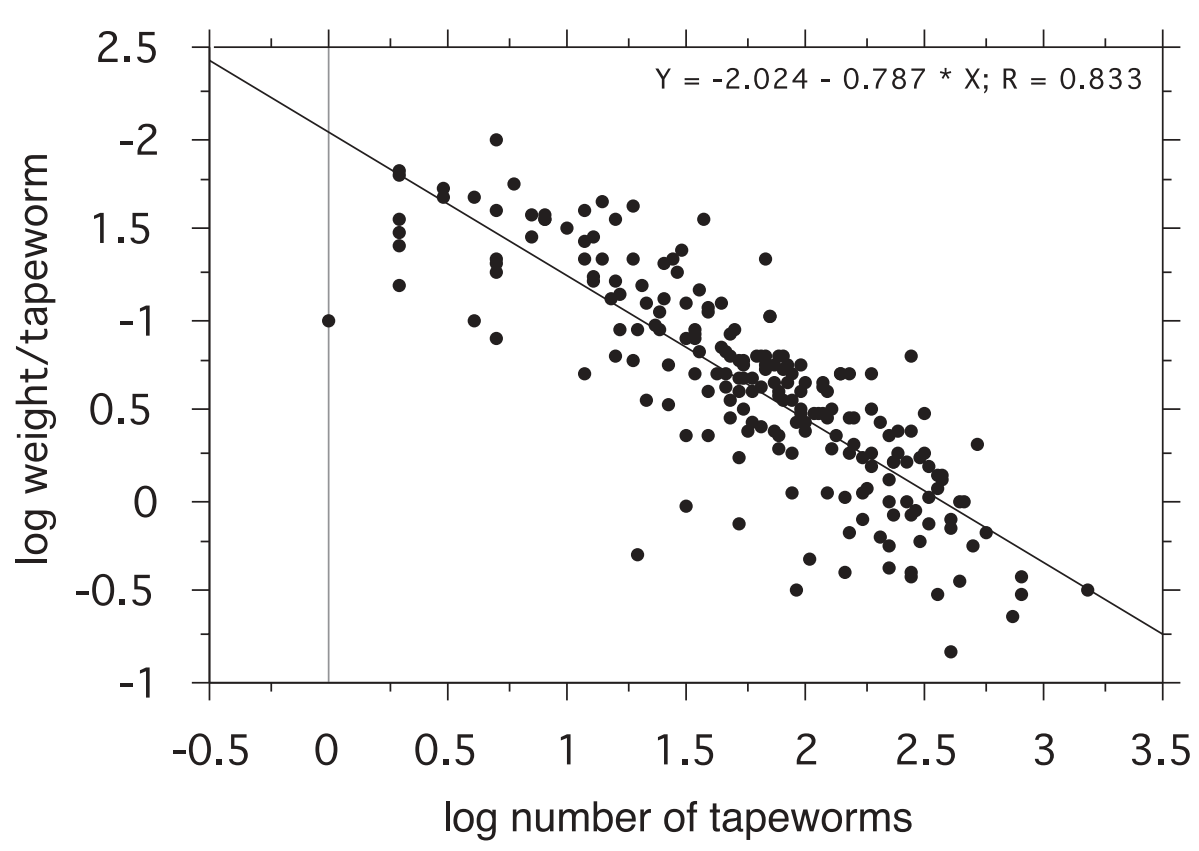

Fig. 7. Negative correlation between the weight by worm and the number of worms reflecting the crowding effect of Raillietina trapezoides in Psammomys obesus.

\section{Crowding effect}

The negative correlation between the weight of individual worms and the number in an infection is a clear illustration of the 'crowding effect'. This effect is well known in other cestode infections, notably Hymenolepis diminuta in Rattus norvegicus (Zavras \& Roberts, 1985; Quinnell, 1988; Hopkins \& Andreassen, 1991). The crowding effect has been widely described, for example in Schistosoma mansoni in hamsters (Coelho et al. 1976) and in Ascaris lumbricoides infections of children in the Philippines (Monzon et al. 1990). In our study, the presence of as few as 5 individual worms reduced their weight by half, and between 5 and 10, the weight of individuals was further halved. Cook \& Roberts (1991) suggested that secretion of inhibitors of DNA synthesis by $H$. diminuta inhibits the growth of worms, and protects the host from dying from excessive burdens. The smaller size also may be a consequence of the immune response as described in the model H. diminuta/R. rattus (Andreassen et al. 1999). The numerous small destrobilated worms in heavily infected hosts support this hypothesis. They rarely carried gravid segments, confirming that the increasing number of worms in $R$. rattus was linked with decreasing fecundity (Hesselberg $\&$ Andreassen, 1975 in Combes, 1995). Additional hypotheses such as the genetic heterogeneity of worms 
and concurrent infections could also explain the crowding effect.

To summarize, in this study the most significant factors predicting both the prevalence and the parasite burden of $R$. trapezoides were season, climatic conditions and host age whereas host density affected intensity only. Host sex did not influence the infection rate or intensity. According to Andreassen et al. (1999), the crowding effect was mainly due to the host's immune response which could emerge by reducing the number of worms when the fat sand rats are old and rare in dry conditions. Despite the mainly folivorous diet of this species (Daly \& Daly, 1973; Zaime \& Gautier, 1989), a complementary insect intake is suspected very early in its life.

This study forms part of a project on the ecological interaction between $P$. obesus and cutaneous leishmaniasis, funded by the Avicenne Programme of the European Commission, AVI CT92/0018. E.F.C. benefitted from a grant from the Société de Secours des Amis des Sciences (Paris). We are grateful to Guila Ganem (Institute for Evolution Sciences at Montpellier II University) and Khiem Dang Van for helping in the statistical analysis and two anonymous reviewers for improving this paper in its earlier version.

\section{REFERENCES}

ANDREASSEN, J., BENNET-JENKINS, E. M. \& BRYANT, C. (1999). Immunology and biochemistry of Hymenolepis diminuta. Advances in Parasitology 42, 223-275.

ASHFORD, R. W. (2000). The leishmaniases as emerging and reemerging zoonoses. International Fournal for Parasitology 30, 1269-1281.

ASHFORD, R. W., SCHNUR, L. F., CHANCE, M. L., SAMAAN, S. A. \& AHMED, H. N. (1977). Cutaneous leishmaniasis in the Libyan Arab Republic: preliminary ecological findings. Annals of Tropical Medicine and Parasitology 71, 265-272.

BEHINKE, J. M., BARNARD, C., HURST, J. L., McGREGOR, P. K., GILBERT, F. \& LEWIS, J. W. (1993). The prevalence and intensity of infection with helminth parasites in Mus spretus from the Setubal Peninsula of Portugal. Fournal of Helminthology 67, 115-122.

BEHNKE, J. M., LEWIS, J. W., MOHD ZAIN, S. N. \& GILBERT, F. S. (1999). Helminth infections in Apodemus sylvaticus in southern England: interactive effects of host age, sex and year on the prevalence and abundance of infections. Fournal of Helminthology 73, 31-44.

BEHNKE, J. M., BARNARD, C. J., MASON, N., HARRIS, P. D., SHERIF, N. E., ZALAT, S. \& GILBERT, F. S. (2000). Intestinal helminths of spiny mice (Acomys cahirinus dimidiatus) from St Katherine's Protectorate in the Sinai, Egypt. Fournal of Helminthology 74, 31-43.

COELHO, P. M., SOUZA, R. C., BREDT, A. \& SOUZA-NETO, J. A. (1976). The crowding effect in Schistosoma mansoni infection of hamsters: influence on worm size. Rev. Inst. Med. Trop. Sao Paulo 18, 440-442. combes, c. (1995). Interactions Durables. Ecologie et Evolution du Parasitisme. Masson, Paris.

COOK, R. L. \& ROBERTS, L. S. (1991). In vivo effects of putative crowding factors on development of Hymenolepis diminuta. Fournal of Parasitology 77, 21-25.

DALY, M. \& DALY, s. (1973). On the feeding ecology of Psammomys obesus (Rodentia, Gerbillidae) in the wadi saoura, Algeria. Mammalia 37, 545-561.

DECKER, K. H., DUSZYNSKI, D. W. \& PATRICK, M. J. (2001). Biotic and abiotic effects on endoparasites infecting Dipodomys and Perognathus species. Fournal of Parasitology 87, 300-307.

DUPLANTiER, J. M. \& SÈNE, M. (2000). Rodents as reservoir hosts in the transmission of Schistosoma mansoni in Richard-Toll, Senegal, West Africa. Fournal of Helminthology 74, 129-135.

FAlissard, B. (2001). Comprendre et Utiliser les Statistiques dans les Sciences de la Vie, 2nd Edn. Masson, Paris.

FICHET-CALVET, E., JOMÂA, I., BEN ISMAIL, R. \& ASHFORD, R. w. (1999). Reproduction and abundance of the fat sand rat (Psammomys obesus) in relation to weather conditions in Tunisia. Fournal of Zoology 248, 15-26.

FICHET-CALVET, E., JOMÂA, I., ZAAFOURI, W., ASHFORD, R. W., BEN ISMAIL, R. \& DELATTRE, P. $(2000 a)$. Spatiotemporal distribution of a rodent reservoir of cutaneous leishmaniasis. Fournal of Applied Ecology 37, 603-615.

FICHET-CALVET, E., JOMÂA, I., BEN ISMAIL, R. \& ASHFORD, R. W. (2000b). Patterns of infection of haemoparasites in the fat sand rat, Psammomys obesus, in Tunisia, and effect on the host. Annals of Tropical Medicine and Parasitology 94, 55-68.

Gaussen, H. (1975). Théorie de la classification des climats et microclimats. Comptes rendus VIIIème Congrès International de Botanique, sect. 7: 125-130.

GODELUCK, B., DUPlantier, J. M., BA, K. \& TRAPE, J. F. (1994). A longitudinal survey of Borrelia crocidurae prevalence in rodents and insectivores in Senegal. American Fournal of Tropical Medicine and Hygiene 50, 165-168.

GUNDERS, A. E., LIDROR, R., MONTILIO, B. \& AMITI, P. (1968). Isolation of Leishmania species from Psammomys obesus in Judea. Transactions of the Royal Society of Tropical Medicine and Hygiene 62, 465.

HaUkisalmi, v. \& HeNTTONEN, H. (1990). The impact of climatic factors and host density on the long-term population dynamics of vole helminths. Oecologia 83, 309-315.

HAUkisalmi, V., HENTTONEN, H. \& TENORA, F. (1988). Population dynamics of common and rare helminths in cyclic vole populations. Fournal of Animal Ecology 62, 221-229.

HOPKINS, C. A. \& ANDREASSEN, J. (1991). Inhibition of growth of a tapeworm Hymenolepis diminuta in its normal host (rat). International Fournal for Parasitology 21, 47-55.

KAM, M. \& DEGEN, A. (1989). Efficiency of use of Saltbush (Atriplex halimus) for growth by fat sand rats (Psammomys obesus). Fournal of Mammalogy 70, 485-493.

KISIELEWSKA, K. (1971). Intestinal helminths as indicators of the age structure of Microtus arvalis Pallas 1778 population. Bulletin de l'Académie Polonaise des Sciences. Séries des Sciences Biologiques 19, 275-282.

LE HOUEROU, H.-N. \& LE FLOC'H, E. (1995). La Végétation potentielle de la Tunisie aride et désertique (Notice 
détaillées de la carte au 1/1 000 000). In Essai de Synthèse sur la Végétation et la Phyto-Ecologie Tunisiennes (ed. Nabli, Md. A.), pp. 389-428. Programme Flore et Végétation Tunisiennes, Faculté des Sciences Press, Tunis.

LORD, R. D. (1959). The lens as an indicator of age in cottontail rabbits. Fournal of Wildlife Management 23, 359-360.

MARGOLIS, L., ESCH, G. W., HOLMES, J. C., KURIS, A. M. \& SCHAD, G. A. (1982). The use of ecological terms in parasitology (report of an ad hoc comittee of the American Society of Parasitologists). Fournal of Parasitology 68, 131-133.

martinet, L. (1966). Détermination de l'âge chez le Campagnol des champs (Microtus arvalis) par le pesée du cristallin. Mammalia 30, 425-430.

Mills, J. N., Ellis, B. A., McKeE, K. T., CALderon, G. E., Maiztegui, J. I., Nelson, G. O., KSIAZEK, T. G., PETers, C. J. \& CHILDS, J. (1992). A longitudinal study of Junin virus activity in the rodent reservoir of Argentine hemorrhagic fever. American Fournal of Tropical Medicine and Hygiene 47, 749-763.

MONTGOMERY, S. S. J. \& MONTGOMERY, W. I. (1988). Cyclic and non-cyclic dynamics in populations of the helminth parasites of wood mice, Apodemus sylvaticus. Fournal of Helminthology 62, 78-90.

MONZON, R. B., CABRERA, B. D., CRUZ, A. C. \& BALTAZAR, J. C. (1990). The 'crowding effect' phenomenon in Ascaris lumbricoides. Southeast Asian Fournal of Tropical Medicine and Public Health 21, 580-585.

MORRIS, P. (1971). A review of mammalian age determination methods. Mammal Review 2, 69-104.

MUNGER, J. C. \& KARASOV, w. H. (1991). Sublethal parasites in white-footed mice: impact on survival and reproduction. Canadian Fournal of Zoology 69, 398-404. OZENDA, P. (1991). Flore et Végétation du Sahara. CNRS. PETTER, F. (1961). Répartition géographique et écologie des rongeurs désertiques. Mammalia 25, 222.
QUINNELL, R. J. (1988). Host age and the growth and fecondity of Hymenolepis diminuta in the rat. Fournal of Helminthology 62, 158-162.

TENORA, F., WIGER, R. \& BARUS, v. (1979). Seasonal and annual variations in the prevalence of helminths in a cyclic population of Clethrionomys glareolus. Holarctic Ecology 2, 176-181.

TURNER, C. M. R. (1986). Seasonal and age distribution of Babesia, Hepatozoon, Trypanosoma and Grahamella species in Clethrionomys glareolus and Apodemus sylvaticus populations. Parasitology 93, 279-289.

WASSOM, D. L., GUSS, v. M. \& GRUNDMANN, A. W. (1973).

Host resistance in a natural host-parasite system. Resistance to Hymenolepis citelli by Peromyscus maniculatus. Fournal of Parasitology 59, 117-121.

WERTHEIM, G., SCHMIDT, G. D. \& GREENBERG, Z. (1986). Witenbergitaenia sinaica gen. n., sp. n.

(Anoplocephalidae) and other Cestodes from small mammals in Israel and in the Sinai Peninsula. Bulletin du Museum d'Histoire Naturelle, Paris, 4e série $\mathbf{8}$, 543-550.

WILSON, K., BJORNSTAD, O. N., DOBSON, A.P., MERLER, S., POGLAYEN, G., RANDOLPH, S. E., READ, A. F. \& SKORPING, A. (2002). Heterogeneities in macroparasite infections: patterns and processes. In The Ecology of Wildlife Diseases (ed. Hudson, P., Rizzoli, A., Grenfell, B. T., Heesterbeek, H. \& Dobson, A. P.), pp. 6-44. Oxford University Press, New York.

Zaime, A. \& GaUtier, J.-Y. (1989). Comparison des régimes alimentaires de trois espèces sympatriques de Gerbillidae en milieu saharien, au Maroc. Revue d'Ecologie (Terre et Vie) 44, 153-163.

ZAVRAS, E. T. \& ROBERTS, L. S. (1985). Developmental physiology of cestodes: cyclic nucleotides and the identity of putative crowding factors in Hymenolepis diminuta. Fournal of Parasitology 71, 96-105. 